\title{
KEBIJAKAN PEMERINTAH DAN DAMPAKNYA DALAM \\ IMPLEMENTASI UPAH BURUH \\ (STUDI KASUS PEMBERIAN UPAH BURUH DI KABUPATEN \\ KARAWANG)
}

\author{
Oleh: \\ Pamungkas Satya Putra \\ Fakultas Hukum Universitas Singaperbangsa, Karawang \\ Email: pamungkas.satya.putra@gmail.com
}

\begin{abstract}
ABSTRAK
Republik Indonesia sebagai negara hukum sebagaimana tertuang dalam UUD NRI Tahun 1945 Pasal 1 ayat (3) menegaskan seluruh aspek pembangunan termasuk ekonomi perlu diatur termasuk penetapan upah minimum yang telah diatur dalam Undang-undang Nomor 13 Tahun 2003 tentang Ketenagakerjaan Pasal 88 sampai dengan Pasal 98 dan peraturan pelaksana lainnya. Dinamika penetapan kebijakan upah minimum dalam bingkai desentralisasi memiliki problematika. Kedudukan pekerja/buruh dan pengusaha serta pemerintah menegaskan peran masing-masing yang saling berhubungan (interdependensi) satu sama lain. Komitmen antara stakeholders di dalam merumuskan, mensosialisasikan dan mengimplementasikan berbagai kebijakan khususnya, penetapan UMK di Kabupaten Karawang yang menjadi kewenangan dari Gubernur berdasarkan rekomendasi Bupati.
\end{abstract}

Kata kunci: Hak Pekerja, Kebijakan, Upah Minimum Kabupaten.

\begin{abstract}
Republic of Indonesia as a state of law embodied in the Constitution Republic of Indonesia State Year 1945 Article 1 (3) confirms all aspects of development including the economy needs to be regulated, including minimum wages that have been regulated in Law Number 13 Year 2003 Article 88 through Article 98 and other implementing regulations. The dynamics of the determination of minimum wage policy within the framework of decentralization has problematic. Position of workers/laborers and employers and the government confirmed the role of each interconnected (interdependence) of each other. Commitment among stakeholders in formulating, disseminating and implementing various policies in particular, the establishment of UMK in Karawang district under the authority of the Governor on the recommendation of the Regent.
\end{abstract}

Keywords: Worker Rights, Policy, District Minimum Wage. 


\section{PENDAHULUAN}

Peranan hukum dalam pembangunan ekonomi memiliki peran yang sangat utama/sentral, di mana berdasarkan Undang-Undang Dasar Negara Republik Indonesia Tahun 1945 Bab I Bentuk dan Kedaulatan Pasal 1 ayat (3) menegaskan bahwa "Negara Indonesia adalah Negara Hukum". Kemudian berdasarkan hal tersebut setiap kegiatan yang berhubungan antara penguasa/ pemerintahan dengan masyarakat (hukum publik) perlu diatur di dalam sebuah peraturan perundangundangan, termasuk penetapan upah minimum yang telah diatur dalam UndangUndang Nomor 13 Tahun 2003 tentang Ketenagakerjaan dan peraturan pelaksanaan lainnya sebagai pengejawantahan negara hukum yang menyejahterakan rakyatnya (welfare of rechtsstaats). ${ }^{1}$

Undang-Undang Dasar Negara Republik Indonesia Tahun 1945 Bab VI Pemerintahan Daerah Pasal 18 ayat (2) menegaskan bahwa "Pemerintahan daerah provinsi, daerah kabupaten dan kota mengatur dan mengurus sendiri urusan pemerintahan menurut asas otonomi dan tugas pembantuan". Hal tersebut merupakan landasan konstitusional dari pemberlakukan penetapan upah minimum dalam mengatur urusan desentralisasi, dekonsentrasi dan tugas pembantuan. Kemudian upah merupakan hak dasar dari seorang pekerja, di mana sudah seharusnya dipenuhi oleh pemberi kerja/pengusaha sebagai kewajiban yang dapat dipergunakan pekerja untuk memenuhi kebutuhan diri sendiri dan/atau keluarganya. Sistem hukum ketenagakerjaan dalam hal ini pengupahan wajib ditinjau dan dikembangkan dengan berdasarkan kepada tiga hal yaitu, struktur pemerintahan (structure), substansi hukum (substance) dan budaya ketenagakerjaan (labour culture) dengan memperhatikan keseimbangan antara prestasi (reward) atau produktivitas kerja, kebutuhan pekerja dan kemampuan perusahaan di setiap wilayah.

Data Badan Pusat Statistik Republik Indonesia pada Tahun 2010 jumlah penduduk Republik Indonesia sebesar 238,5 Juta Jiwa yang diproyeksikan pada

1 Erman Radjagukguk, "Peranan Hukum Dalam Pembangunan Pada Era Globalisasi: Implikasinya Bagi Pendidikan Hukum Di Indonesia". Pidato pengukuhan diucapkan pada upacara penerimaan jabatan Guru Besar dalam bidang hukum pada Fakultas Hukum Universitas Indonesia, Jakarta, 4 Januari 1997. 
tahun 2035 akan mencapai 305,6 Juta Jiwa. Hal tersebut menegaskan akan terjadi kepadatan penduduk Republik Indonesia karena persebaran penduduk yang tidak sama antara pulau satu dengan pulau lainnya (Badan Pusat Statistik (BPS) dan United Nation Population Fund (UNPF): 23-25). Data tersebut menegaskan bahwa pada tahun 2035 Republik Indonesia sebagai negara dengan populasi terbesar kelima setelah Nigeria, Amerika Serikat, India dan China. Persebaran penduduk Republik dapat dilihat pada Gambar di bawah ini :

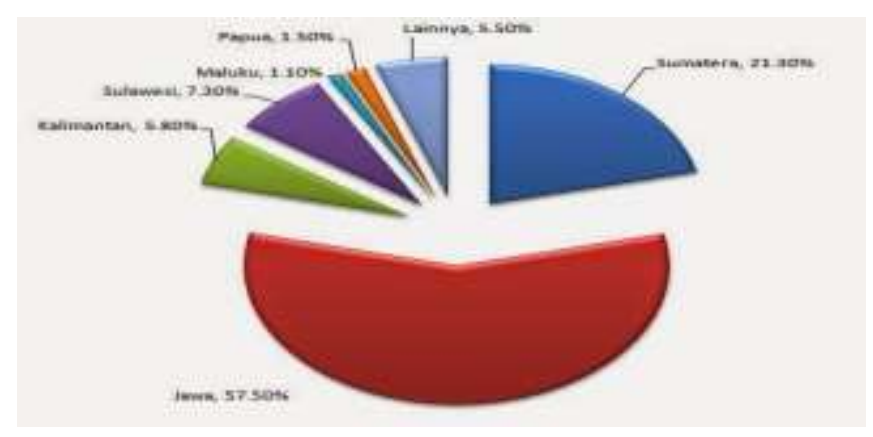

Gambar 1. Diagram Persebaran Penduduk Indonesia (Badan Pusat Statistik (BPS) dan United Nation Population Fund (UNPF): 26-28).

Berdasarkan data tersebut setidak-tidaknya telah terjadi ancaman kepadatan penduduk Republik Indonesia yang tidak merata, yaitu potensi terjadi ledakan penduduk di wilayah, seperti di Pulau Jawa. Berdasarkan hal tersebut, maka dapat disimpulkan bahwa jumlah penduduk yang banyak tidak sepadan dengan jumlah lapangan pekerjaan yang ada di setiap wilayah. Sumber daya manusia atau tenaga kerja yang ada harus diimbangi dengan lapangan pekerjaan yang sesuai dengan jumlah sumber daya manusia tersebut. Perlu adanya pengembangan percepatan basis wilayah tertinggal dan wilayah berkembang. Adapun jumlah pekerja di Republik Indonesia, yaitu mencapai 125,3 juta pekerja atau mencapai hampir 50\% dari jumlah penduduk.

Jumlah penduduk di Kabupaten Karawang berdasarkan data statistik Badan Statistik Kab. Karawang pada tahun 2014 mencapai 2.250.120 juta jiwa, pada tahun 2013 mencapai 2.225.357 juta jiwa dan pada tahun 2012 mencapai 2.199.444 juta jiwa atau setidak-tidaknya per satu tahun laju pertumbuhan penduduk tahun 2012 sampai dengan tahun 2014 mengalami kenaikan sebesar 1\% 
sampai dengan 2,5\%. Hal tersebut dapat dilihat dalam Tabel 1.1 Jumlah Penduduk Kabupaten Karawang.

\begin{tabular}{|l|l|l|c|c|}
\hline \multirow{2}{*}{ No. } & \multicolumn{3}{|c|}{ Uraian } & \multicolumn{3}{c|}{ Tahun } \\
\cline { 3 - 5 } & & \multicolumn{1}{|c|}{$\mathbf{2 0 1 2}^{*}$} & $\mathbf{2 0 1 3}$ & \multicolumn{1}{|c|}{$\mathbf{2 0 1 4}$} \\
\hline 1. & Jumlah Penduduk & 2.199 .444 & 2.225 .357 & 2.250 .120 \\
\hline 2. & Komposisi menurut Jenis Kelamin & & & \\
\hline & a.Pria & 1.133 .830 & 1.147 .1888 & 1.154 .982 \\
\hline & b.Wanita & 1.065 .614 & 1.078 .169 & 1.095 .138 \\
\hline 3. & Pertumbuhan (LPP\%) & 1,32 & 1,18 & 1,11 \\
\hline 4. & Tingkat Kepadatan Penduduk $\left(\right.$ per $\left.\mathrm{Km}^{2}\right)$ & 1.254 & 1.269 & 1.283 \\
\hline
\end{tabular}

Tabel 1. Jumlah Penduduk Kabupaten Karawang

Sumber: BPS Kabupaten Karawang

Keterangan: *) = angka sangat sementara

Jumlah pekerja dari seluruh lapangan usaha yaitu pertanian dan perikanan, perdagangan, industri dan seluruh lapangan usaha lainnya pada tahun 2012 mencapai 1.606.453 juta jiwa, pada tahun 2013 mencapai 1.495.418 juta jiwa, kemudian pada tahun 2014 mencapai 1.567 .940 juta jiwa. Hal tersebut dapat dilihat dalam Tabel 1.2 Komposisi Penduduk Kabupaten Karawang Menurut Lapangan Usaha Tahun 2012-2014.

\begin{tabular}{|l|l|l|l|l|}
\hline No. & Lapangan Usaha & \multicolumn{3}{l|}{ Tahun } \\
\cline { 3 - 5 } & & $\mathbf{2 0 1 2}$ & $\mathbf{2 0 1 3}$ & $\mathbf{2 0 1 4}$ \\
\hline 1. & Pertanian dan Perikanan & 168.224 & 141.219 & 160.819 \\
\hline 2. & Perdagangan & 277.808 & 264.727 & 266.962 \\
\hline 3. & Industri & 242.865 & 214.259 & 227.295 \\
\hline 4. & Seluruh Lapangan usaha & 917.556 & 875.213 & 912.864 \\
\hline
\end{tabular}

Tabel 2. Komposisi Penduduk Kabupaten Karawang Menurut Lapangan Usaha

Tahun 2012-2014

Sebagaimana diatur di dalam Undang-Undang Dasar Negara Republik Indonesia Tahun 1945 Bab X Warga Negara dan Penduduk Pasal 27 ayat (2) bahwa "Tiap-tiap warga negara berhak atas pekerjaan dan penghidupan yang layak bagi kemanusiaan”, serta perubahan kedua (tahun 2000) Undang-Undang Dasar Negara Republik Indonesia Tahun 1945 Bab XA Hak Asasi Manusia Pasal 28D ayat (2) bahwa "Setiap orang berhak untuk bekerja serta mendapat imbalan

\footnotetext{
${ }^{2}$ Berdasarkan data yang telah diolah oleh Badan Pusat Statistik Kabupaten Karawang.
} 
dan perlakuan yang adil dan layak dalam hubungan kerja". ${ }^{3}$ Hukum dasar di Republik Indonesia tersebut merupakan landasan konstitusional dari hak dasar yang berlaku untuk seluruh rakyat Republik Indonesia. Pemerintah memiliki tugas dan wewenang serta tanggung jawab untuk melaksanakan sebagaimana termaktum dalam Pembukaan Undang-Undang Dasar Negara Republik Indonesia Tahun 1945 alinea keempat bahwa untuk "memajukan kesejahteraan umum" berdasarkan Pancasila, untuk tercapainya "keadilan sosial bagi seluruh rakyat Indonesia" sebagai dasar konstitusionalisme ketenagakerjaan di Republik Indonesia.

Komitmen antara stakeholders (pemerintah, pengusaha, dan masyarakat) di dalam merumuskan, mensosialisasikan dan mengimplementasikan berbagai kebijakan khususnya, misalnya penetapan upah minimum kabupaten (UMK) di Kabupaten Karawang yang menjadi kewenangan dari Gubernur, hak dari para pekerja, serta kewajiban bagi para pengusaha merupakan dimensi sosial dan ekonomi berlandaskan hukum dalam mengatur, memaksa dan memberikan sanksi bagi yang melanggar hukum (R Soedarmoko: 1-4). Hukum sebagai sarana perubahan dan sarana pengendalian di dalam konteks penetapan upah merupakan landasan dari perubahan menuju kesejahteraan pekerja dan sebagai sarana pengendalian di dalam membatasi munculnya pencari kerja (population boms) di Kabupaten Karawang. Maka konteks hukum sebagai ilmu pengetahuan yang bersifat interdisipliner menegaskan dominasi hukum dalam pergaulan hidup manusia, di mana hukum juga dipergunakan sebagai sarana pembangunan ekonomi nasional atau dapat juga disebut dengan law as a tool of development of national economic. ${ }^{4}$

${ }^{3}$ Undang-Undang Dasar Negara Republik Indonesia Tahun 1945 tersebut, menegaskan bahwa keseja-hteraan adalah kemampuan warga negara untuk menjalani kehidupan dan pekerjaan yang layak. Setiap warga negara pada dasarnya memiliki keinginan untuk berkehidupan dan bekerja secara layak agar mendapatkan kehidupan yang sejahtera, karena kehidupan sejahtera adalah hak bagi setiap warga negara Republik Indonesia.

${ }^{4}$ Pandangan tersebut dikembangkan dari pendapat Kohler, Ahler dan Roscoe Pound tentang Law as a tool of social engineering. Undang-undang Nomor 13 Tahun 2003 tentang Ketenagakerjaan Pasal 32, mengamanatkan bahwa dalam pelayanan penempatan tenaga kerja dilaksanakan secara terbuka, bebas, obyektif serta adil dan setara tanpa diskriminasi. Lihat juga International Labour Organization, Indonesia: Tren Sosial dan Ketenagakerjaan Agustus 2014, (Jakarta: Asian Decent Work Decade, 2014), hal. 1-4. 
Dunia usaha yang bersinggungan langsung dengan dimensi sosial, ekonomi dan lingkungan menyebabkan pemerintah berdasarkan hak penguasaan negara melakukan pengaturan untuk mempertahankan dan mengembangkan iklim investasi dengan cara melakukan pengaturan hukum di bidang ketenagakerjaan. Adapun dalam ruang lingkup ketenagakerjaan, terdapat pengaturan tentang hubungan hukum antara orang dengan orang atau orang dengan badan hukum atau badan hukum dengan badan hukum, di mana terikat dengan hubungan ketenagakerjaan, yaitu antara buruh/pekerja dengan pemberi kerja. Pemberi kerja memberikan pekerjaan yang harus dikerjakan oleh pekerja dan diperjanjikan (baik melalui Perjanjian Kerja Waktu Tertentu (PKWT) maupun Perjanjian Kerja Waktu Tidak Tentu (PKWTT) akan diberikan upah/imbalan di satu sisi sebagai bentuk hak bagi pekerja dan disisi lain sebagai bentuk kewajiban pemberi kerja. Hal tersebut bukan hanya untuk menjaga hak dari kepentingan para pekerja saja, akan tetapi juga mengatur para pengusaha untuk bertindak berdasarkan peraturan perundang-undangan. Berdasarkan hal inilah maka penulis melakukan penelitian dengan judul "Kebijakan Pemerintah dan Dampaknya Dalam Implementasi Upah Buruh (Studi Kasus Pemberian Upah Buruh Di Kabupaten Karawang)”.

\section{Pengaturan Upah Buruh dan Dinamikanya}

Semua corak, bentuk, bangunan dan struktur organisasi yang ada hanyalah mencerminkan respons negara dan para pengambil keputusan (decision makers). Hal tersebut dimaksudkan dalam suatu negara dilakukan pengorganisasian berbagai kepentingan yang terdapat dalam tiap-tiap negara. Kemudian Teori hierarki norma (stufentheorie) yang dikemukakan Hans Kelsen dan teori hierarki norma hukum (die theorie vom stufentordnung der rechtsnormen) yang dikemukakan Hans Nawiansky dapat digunakan untuk menjelaskan sistem norma hukum di Republik Indonesia. Kemudian pentingnya produk hukum serta konstruksi sistem hukum dalam suatu lembaga negara menjadi hal penting dalam melindungi kepentingan warga negara. Dalam tata hukum di Indonesia mengadopsi The Legal Order is a system of norms menurut Hans Kelsen dapat diketahui sistem hukum di Republik Indonesia merupakan hierarki dan bersumber pada norma dasar atau kaidah paling tinggi yaitu Undang Undang Dasar Negara 
Republik Indonesia Tahun 1945. Menurut Kelsen, norma dasar itu akan menjadi sumber hukum, sebagai norma tertinggi yang menjadi sumber norma dibawahnya.

Kebijakan yang mereduksi regulasi, governance (tata pemerintahan) dan risk (risiko) merupakan hukum yang ideal dalam bentuk mengawal dari upaya menghindari kemerosotan akan kepercayaan dan ketidakpatuhan terhadap hukum. Aspek-aspek tersebut yang seyogyanya merupakan landasan dari pembentukan kebijakan yang bersifat langsung mengatur melalui desentralisasi berupa penetapan upah minimum kabupaten (UMK) di Kabupaten Karawang. Dasar hukum penetapan upah minimum adalah Undang-undang Nomor 13 Tahun 2003 tentang Ketenagakerjaan Pasal 1 angka 30 vide. Pasal 88 sampai dengan Pasal 98 Juncto. Peraturan Pemerintah Nomor 78 Tahun 2015 tentang Pengupahan sebagaimana mencabut Peraturan Pemerintah Nomor 8 Tahun 1981 tentang Perlindungan Upah Juncto. Peraturan Menteri Tenaga Kerja dan Transmigrasi Nomor 7 Tahun 2013 tentang Upah Minimum. Upah minimum ditetapkan oleh Gubernur dengan memperhatikan rekomendasi Dewan Pengupahan Provinsi, Bupati/Wali Kota berdasarkan rekomendasi Dewan Pengupahan Kabupaten/Kota. Penetapan upah dilaksanakan setiap tahun melalui proses yang panjang.

Dewan Pengupahan Provinsi/Kabupaten/Kota (Depenas/Depekab/Depeko) yang terdiri dari unsur pemerintah, buruh, pengusaha dan satu orang unsur akademisi, mengadakan rapat, membentuk tim survei dan turun ke lapangan "survei" mencari nilai harga sejumlah kebutuhan yang dibutuhkan oleh pegawai, karyawan dan buruh. Setelah survei di sejumlah kota dalam provinsi tersebut yang dianggap representatif, diperoleh angka Kebutuhan Hidup Layak (KHL) yang kemudian disebut Kebutuhan Hidup Minimum (KHM). Berdasarkan KHL, Dewan Pengupahan Provinsi mengusulkan upah minimum kepada Gubernur untuk disahkan. Komponen kebutuhan hidup layak digunakan sebagai dasar penentuan upah minimum berdasarkan kebutuhan hidup pekerja lajang (belum menikah). Hal tersebut perlu untuk dirubah bukan lagi berdasarkan kebutuhan hidup pekerja lajang, akan tetapi kebutuhan hidup satu istri dan dua anak. ${ }^{5}$

Lebih jauh dinyatakan oleh Imam Soepomo, bahwa upah merupakan pembayaran yang diterima buruh selama melakukan pekerjaan atau dipandang

${ }^{5}$ Lihat Peraturan Menteri Tenaga Kerja dan Transmigrasi Nomor 7 Tahun 2013 tentang Upah Minimum. 
melakukan pekerjaan. Dipandang dari sudut pandang nilainya, upah itu dibedabedakan antara upah nominal yaitu jumlah yang berupa uang dan upah riil yaitu banyaknya barang yang dapat dibeli dengan jumlah uang itu. Pada masa zaman pasca kemerdekaan, buruh lebih menginginkan pembayaran dilakukan dengan upah riil, karena dirasakan sulit untuk mendapatkan cukup barang yang diperlukan untuk kehidupan sehari-harinya. Kemudian, kenaikan upah nominal tidak berarti apapun, karena nilai nominal tersebut sulit untuk dipergunakan (Imam Soepomo: 31-32 dan 179-182). Dalam pemberian upah berupa barang tersebut, harus dijaga supaya buruh tidak dirugikan dengan pemberian barang yang tidak langsung diperlukan oleh buruh di bawah nilai dari pekerjaan yang telah dilakukan oleh buruh. Adapun untuk mencegah pembayaran upah dengan barang yang dihasilkan oleh perusahaan yang tidak langsung diperlukan untuk penghidupan sehari-hari (Truckstelsel), Kitab Undang-undang Hukum Perdata melarang pemberian barang kepada buruh yang tidak bertempat tinggal pada pemberi kerja.

Pasal 93 menegaskan pelaksanaan asas yang berlaku secara universal untuk semua pekerja/buruh sebagai hak dasar pekerja/buruh itu sendiri. Upah tidak dibayarkan apabila pekerja/buruh tidak melakukan pekerjaan, kecuali apabila pekerja/buruh yang bersangkutan tidak dapat melakukan pekerjaan bukan karena kesalahannya sendiri, sebagaimana diatur di dalam Pasal 93 ayat (2) (Asas no work no pay tidak berlaku dan pengusaha tetap wajib membayar upah). Asas ini sering disebut asas no work no pay atau tidak bekerja maka tidak dibayar. Namun, asas ini tidak berlaku mutlak. Artinya, walaupun tidak bekerja, pekerja/buruh tetap mendapatkan upah. Dapat disimpulkan bahwa di Republik Indonesia sejak kemerdekaan hingga saat ini pengaturan upah buruh didasarkan pada asas tidak bekerja maka tidak dibayar relatif atau no work no pay relative principle bukan didasarkan kepada asas tidak bekerja maka tidak dibayar atau no work no pay absolute principle.

Penetapan besarnya upah minimum yang berubah-ubah, di mulai dari penetapan yang dilakukan oleh Menteri, Gubernur hingga rekomendasi yang dilakukan oleh Kepala Daerah Kabupaten/Kota kepada Gubernur dalam menentukan upah minimum Kabupaten/Kota. Perlunya penerapan sistem setiap kepala daerah berhak untuk menentukan upah minimum di wilayahnya masing- 
masing, karena dianggap sangat mengetahui indikator-indikator dasar di dalam penetapan kebijakan upah minimum. Hal tesebut harus diselaraskan dengan konsep pengawasan yang benar. Pengawasan tersebut secara periodik harus dilakukan oleh pemerintah pusat dan pemerintah daerah. Menteri, Gubernur atau Bupati/Wali Kota sesuai dengan kewenangannya, wajib melakukan pengawasan terhadap ketaatan pengusaha dalam menerapkan upah minimum. Menteri, gubernur atau bupati/walikota sesuai dengan kewenangannya dapat mendelegasikan kewenangannya dalam melakukan pengawasan kepada pejabat/instansi teknis yang bertanggung jawab di bidang ketenagakerjaan.

Konsep pembaharuan hukum harus melakukan optimalisasi kedudukan Menteri di mana dapat melakukan pengawasan terhadap ketaatan pengusaha di wilayah Pemerintah Daerah jika Pemerintah menganggap terjadi pelanggaran yang serius di bidang penerapan upah minimum bagi pekerja/buruh sebagai bentuk second line infection atau pengawasan lini kedua secara langsung yang dilakukan oleh Menteri. Kemudian Menteri dapat menerapkan sanksi administratif terhadap pengusaha jika Pemerintah menganggap Pemerintah Daerah secara sengaja tidak menerapkan pengawasan dan sanksi administratif terhadap pelanggaran yang serius di bidang penerapan upah minimum terhadap pekerja/buruh sebagai bentuk second line enforcement atau pemberian sanksi lini kedua yang langsung dilakukan oleh menteri apabila dipahami bahwa telah terjadi pelanggaran, dan Pemerintahan Daerah secara nyata tidak melakukan tindakan apapun. Sanksi administratif terdiri atas: a. teguran tertulis; b. paksaan pemerintah (misalnya ketaatan terhadap peraturan perundang-undangan); c. pembekuan usaha; atau d. pencabutan izin usaha. Penetapan upah minimum merupakan bentuk pelaksanaan dari hak dasar/utama pekerja/buruh di mana keseimbangan antara kepentingan pekerja/buruh dengan pengusaha merupakan faktor utama yang perlu diperhatikan dalam penetapan Upah Minimum. Di satu sisi peningkatan upah minimum akan mengakibatkan bertambahnya biaya produksi yang dibebankan kepada perusahaan, akan tetapi di sisi lain peningkatan upah minimum bagi pekerja/buruh dapat meningkatkan kesejahteraan dalam konsep kemanusiaan (human dignity-manusia yang memanusiakan manusia). Peningkatan upah minimum harus diupayakan berkembang dari waktu ke waktu didasarkan 
kepada bahwa manusia dan kehidupannya itu bergerak dinamis dan pergerakan tersebut harus didasarkan pada faktor sosial, ekonomi dan lingkungan.

Terjadi pergeseran paradigma sistem pengupahan nasional dan sub-nasional yang berawal dari generalisasi penetapan upah minimum menjadi spesialisasi penetapan upah minimum berdasarkan kategori tertentu. Berdasarkan hal tersebut maka dapat dijelaskan bahwa dalam sistem pengupahan nasional dan sub-nasional mempergunakan teori species payment atau sistem pengupahan khusus berdasarkan kategori tertentu (teori generalisasi dan spesialisasi pengupahan). Hal tersebut ditegaskan dalam Penjelasan Pasal 89 Undang-undang Nomor 13 Tahun 2003 tentang Ketenagakerjaan dan Intruksi Presiden Nomor 9 Tahun 2013 tentang Kebijakan Penetapan Upah Minimum Dalam Rangka Keberlangsungan Usaha dan Peningkatan Kesejahteraan Pekerja, khusus kepada Menteri Tenaga Kerja dan Transmigrasi, untuk: ${ }^{6}$

a. Merumuskan dan menetapkan kebijakan pengupahan dan pengembangan sistem pengupahan nasional dengan ketentuan:

1) Upah Minimum didasarkan pada Kebutuhan Hidup Layak (KHL), produktivitas, dan pertumbuhan ekonomi;

2) Upah Minimum provinsi/kabupaten/kota diarahkan kepada pencapaian KHL;

3) Untuk daerah yang Upah Minimumnya masih berada di bawah nilai KHL, kenaikan Upah Minimum dibedakan antara Industri Padat Karya tertentu dengan industri lainnya;

4) Besaran kenaikan upah pada provinsi dan/atau kabupaten/kota yang upah minimumnya telah mencapai KHL atau lebih, ditetapkan secara bipartit antara pemberi kerja dan pekerja dalam perusahaan masingmasing;

b. Melakukan koordinasi dengan menteri terkait dalam rangka mengklasifikasikan kenaikan Upah Minimum sebagaimana dimaksud pada huruf a angka (3).

Dalam penetapan kebijakan tentang upah minimum selalu menghadirkan dinamika dalam dua sisi, di mana di satu sisi akan menerima dan sisi lain akan

${ }^{6}$ Lihat Intruksi Presiden Nomor 9 Tahun 2013 tentang Kebijakan Penetapan Upah Minimum Dalam Rangka Keberlangsungan Usaha dan Peningkatan Kesejahteraan Pekerja. 
menolak dengan berbagai macam alasan logis. Inti dari penetapan upah minimum adalah menjamin kedudukan pekerja/buruh sebagai bagian dari penegasan hakhak pekerja dan kewajiban-kewajiban pekerja. Adapun Gambar 2. tentang Sustainability Paradigm of Payment dapat menggambarkan siklus dalam hubungan antara pekerja/buruh dengan penguasa, di mana akan terdapat dua kesimpulan, bahwa:

a. Penetapan upah rendah dari KHL akan menyebabkan perusahaan menjadi kuat (strong), karena biaya produksi yang minimal dengan keuntungan yang maksimal, sebaliknya hal tersebut akan membuat pekerja/buruh diposisi lemah (weak) di mana tidak akan mencapai kesejahteraan terutama KHL dan daya beli terus menurun serta selalu akan terjadi mogok kerja untuk menuntut hak-hak pekerja (karena mogok kerja akan selalu ada sampai tidak ada lagi hak-hak pekerja yang dituntut);

b. Penetapan upah minimam sesuai bahkan lebih dari KHL akan menyebabkan perusahaan menjadi lemah (weak), karena biaya produksi yang maksimal dengan keuntungan yang minimal, sebaliknya hal tersebut akan membuat pekerja/buruh diposisi kuat (strong) di mana pekerja/buruh dapat mencapai kesejahteraan terutama KHL dan daya beli terus meningkat serta rentan Pemutusan Hubungan Kerja karena kedudukan perusahaan relatif labil dengan tingkat penurunan drastis hingga dapat menyebabkan perusahaan memutuskan untuk pindah lokasi bahkan penutupan. Kendati demikian pengaturan Kebutuhan Hidup Layak (KHL) yang dilakukan oleh pemerintah merupakan penekanan kepada pelaku usaha untuk menyeimbangkan posisi antara pengusaha dan pekerja/buruh. 


\section{Sustainability Paradigms fo Payment}

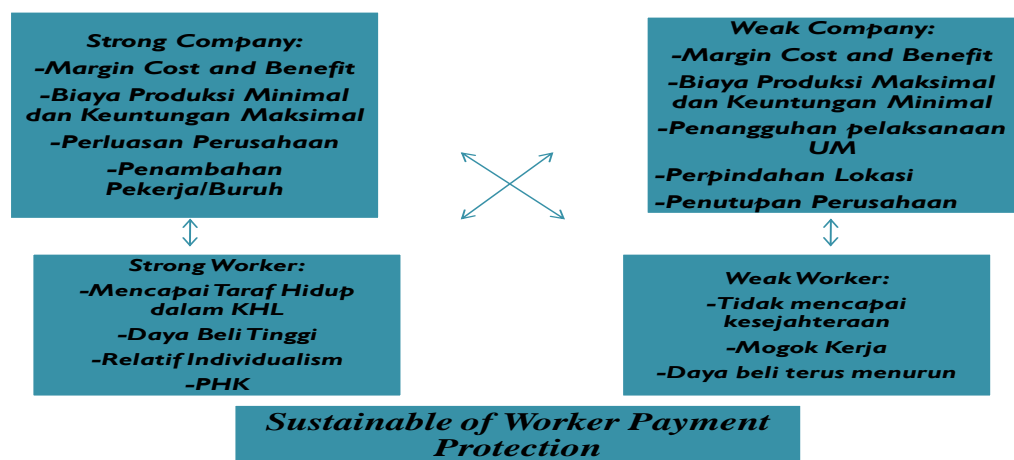

Gambar 2. Sustainability Paradigm of Payment

\section{PENUTUP}

\section{Kesimpulan :}

1. Tujuan buruh melakukan pekerjaan yaitu untuk mendapatkan penghasilan cukup untuk membiayai kehidupannya bersama dengan keluarganya, yaitu penghitungan yang layak bagi manusia yang kemudian dapat disebut dengan upah. Kendati Peraturan Pemerintah Tahun 78 Tahun 2015 tentang Pengupahan menimbulkan dinamika dalam penetapan upah untuk pekerja/buruh yang masa kerja lebih dari satu (1) tahun melalui mekanisme bipartit, akan tetapi apabila didasarkan pada Undang-Undang Nomor 13 Tahun 2003 tentang Ketenagakerjaan Pasal 91 ayat (1). Dalam pengaturan tentang upah pekerja/buruh dalam Undang-Undang Nomor 13 Tahun 2003 tentang Ketenagakerjaan Bab XVI Ketentuan Pidana dan Sanksi Administratif Pasal 185 dan Pasal 186 terdapat ketentuan pidana terhadap bentuk delik pelanggaran dan/atau kejahatan. Pertama, tindak pidana kejahatan bagi orang maupun badan hukum dan/atau badan usaha, dalam hal ini bertanggung jawab mutlak (strict liability: person liability and/or coorporate liability), di mana pengusaha dilarang membayar upah lebih rendah dari upah minimum sebagaimana diatur di dalam Upah Minimum Provinsi atau Upah Minimum Kabupaten/Kota dengan ancaman hukuman sanksi pidana penjara paling singkat 1 (satu) tahun dan paling 
lama 4 (empat) tahun dan/atau denda paling sedikit Rp. 100.000.000,00 (seratus juta rupiah) dan paling banyak Rp. 400.000.000,00 (empat ratus juta rupiah) termasuk pemenuhan hak-hak dan/atau ganti rugi terhadap pekerja/buruh. Kedua, tindak pidana pelanggaran yaitu pengusaha wajib membayar upah sebagaimana diatur dalam Pasal 93 ayat (2), apabila hal tersebut diingkari oleh pengusaha, diancam dengan sanksi pidana penjara paling singkat 1 (satu) tahun dan paling lama 4 (empat) tahun dan/atau denda paling sedikit Rp. 100.000. 000,00 (seratus juta rupiah) dan paling banyak Rp. 400.000.000,00 (empat ratus juta rupiah). Apabila dicermati dengan lebih seksama, di dalam ancaman hukuman yang diterapkan di dalam kedua (2) pasal tersebut pada intinya sama dan tidak membedakan tujuan dari pemisahan konsep kejahatan dan pelanggaran dalam hukum pidana, seperti kejahatan perseorangan dan kejahatan koorporasi maupun pelanggaran perseorangan dan pelanggaran koorporasi.

2. Seluruh peraturan yang telah di analisis pada intinya bertujuan untuk melindungi pekerja/buruh sebagai pihak yang memiliki posisi lemah, serta meningkatkan taraf hidup pekerja/buruh dan keluarganya dan mencegah terjadinya kemerosotan penghasilan dan daya beli secara fluktuatif. Pengaturan upah lintas provinsi diatur dalam Peraturan Daerah Provinsi Jawa Barat Nomor 6 Tahun 2014 tentang Penyelenggaraan Ketenagakerjaan Juncto. Peraturan Daerah Kabupaten Karawang Nomor 1 Tahun 2011 tentang Penyelenggaraan Ketenagakerjaan Bab X Perlindungan, Pengupahan dan Jaminan Sosial Pasal 35 sampai dengan Pasal 37. Perda tersebut menegaskan bahwa setiap pekerja/buruh berhak memperoleh penghasilan yang memenuhi penghidupan yang layak bagi kemanusiaan sesuai dengan ketentuan peraturan perundang-undangan. Seluruh peraturan yang telah dikemukakan tersebut bertujuan untuk melindungi pekerja/buruh sebagai pihak yang memiliki posisi lemah, serta meningkatkan taraf hidup pekerja/buruh dan keluarganya dan mencegah terjadinya kemerosotan penghasilan dan daya beli secara fluktuatif. Penetapan besarnya upah minimum yang berubah-ubah, di mulai dari penetapan yang dilakukan oleh Menteri, Gubernur hingga rekomendasi 
yang dilakukan oleh Kepala Daerah Kabupaten/Kota kepada Gubernur dalam menentukan upah minimum Kabupaten/Kota.

3. Ketidaksesuaian masyarakat dalam konteks penerimaan terhadap kebijakan penetapan upah minimum kabupaten (UMK) saat ini lebih banyak disikapi terhadap ketidakpuasan sebagian manusia atas apa yang telah diterima merupakan alasan yang klasik disampaikan oleh kaum pengusaha. Ketentuan tentang penetapan upah minimum kabupaten (UMK) memiliki peranan atas kehidupan pekerja secara langsung dalam bagaimana pengusaha melaksanakannya tanpa berdalih atas sebagian keuntungan dengan profit oriented yang berbeda tiap waktunya. Kewajiban tersebut harusnya memiliki sanksi yang cukup relevan baik penegakan hukum administrasi (pengawasan dan pengendalian), hukum perdata (ganti rugi) hingga hukum pidana (efek derita atau jera). Adapun dampak penetapan upah minimum bagi para pelaku usaha yaitu berupa penangguhan pelaksanaan upah minimum tahun 2015-2014. Penangguhan Upah Minimum Kabupaten Karawang Tahun 2015 didasarkan pada Keputusan Gubernur Jawa Barat Nomor: 561/Kep/132-Bangsos/2015 tentang Persetujuan dan Penolakan Penangguhan Pelaksanaan Upah Minimum Kabupaten Karawang Tahun 2015 yang diajukan oleh tiga puluh empat (34) perusahaan, diantaranya tiga puluh tiga perusahaan (33) disetujui waktu penangguhannya selama 12 bulan dan satu (1) perusahaan ditolak. Penangguhan Upah Minimum Kabupaten Karawang Tahun 2014 didasarkan pada Keputusan Gubernur Jawa Barat Nomor: 561/Kep.128Bangsos/2014 Kabupaten Karawang tentang Izin Penangguhan Pelaksanaan Upah Minimum Kabupaten/Kota di Jawa Barat Tahun 2014 Kepada Perusahaan di Kabupaten Karawang yang diajukan oleh dua puluh sembilan (29) perusahaan dan disetujui untuk ditangguhkan selama dua belas (12) bulan. 


\section{DAFTAR PUSTAKA}

\section{Buku dan artikel ilmiah}

Khakim, Abdul. Dasar-Dasar Hukum Ketenagakerjaan Indonesia. Bandung: Citra Aditya Bakti. 2009.

Agusmidah. Dilematika Hukum Ketenagakerjaan Tinjauan Politik Hukum. Jakarta: Softmedia. 2011.

.Hukum Ketenagakerjaan Indonesia. Bogor: Ghalia Indonesia. 2010.

Arinanto, Satya. Hak Asasi Manusia dalam Transisi Politik di Indonesia. Jakarta: Pusat Studi Hukum Tata Negara. Fakultas Hukum Universitas Indonesia. 2008.

.Politik Hukum 2. Jakarta: Pascasarjana Fakultas Hukum Universitas Indonesia. 2001.

Asshiddiqie, Jimly. Perkembangan dan Konsolidasi Lembaga Negara Pasca Reformasi. Jakarta: Sinar Grafika. 2012.

.Konstitusi dan Konstitusionalisme. Jakarta: Sinar Grafika.

2010.

Asshiddiqie, Jimly. Mahkamah Konstitusi Dalam Sistem Ketatanegaraan Republik Indonesia. Makalah. Bahan ceramah pada Pendidikan Sespati dan Sespim Polri. Bandung. 19 April 2008.

Badan Perencanaan Pembangunan Nasional (BAPPENAS), Badan Pusat Statistik (BPS) dan United Nation Population Fund (UNPF), Proyeksi Penduduk Indonesia (Indonesia Population Projection) 2010-2035. Jakarta: BPS, 2015.

Bambang, R. Joni. Hukum Ketenagakerjaan. Bandung: Pustaka Setia. 2013.

Basiang, Martin. Law Dictionary First Edition. Jakarta: Red and White Publishing, 2009.

Burhan, Ashshofa. Metode Penelitian Hukum. Jakarta: Rineka Cipta, 2010.

Cholid, Narbuko., Abu Achmadi. Metodologi Penelitian. Bandung: Bumi Aksara, 2002. 
Djumialdji, F.X. Kedudukan Kesepakatan Kerja Bersama dalam Hubungan Industrial Pancasila (HIP). Jakarta: Rajawali Pers, 1995. . Perjanjian Kerja. Jakarta: Sinar Grafika, 2006.

Fajar, Mukti. Et. Al. Dualisme Penelitian Hukum Normatif dan Empiris. Yogyakarta: Pustaka Pelajar, 2010.

Ibrahim, Jonny. Teori dan Metodologi Hukum. Surabaya: Radjawali Press, 2005.

International Labour Organization. Indonesia: Tren Sosial dan Ketenagakerjaan Agustus 2014. Jakarta: Asian Decent Work Decade, 2014.

Khakim, Abdul. Aspek Hukum Penyelesaian Perselisihan Hubungan Industrial (Antara Peraturan dan Pelaksanaan). Bandung: PT. Citra Aditya Bakti, 2010.

Libertus Jehani. Hak-hak Pekerja Bila di PHK. Jakarta: Visimedia, 2006.

Mahkamah Agung R.I dan Fakultas Hukum Universitas Indonesia. Sistem Hukum Indonesia. Jakarta: Mahkamah Agung Republik Indonesia, 2005.

Malau, Parningota. Perlindungan Hukum Pekerja/Buruh Atas Keselamatan dan Kesehatan Kerja. Jakarta: P.T. Sofmedia, 2013.

Mulyadi, Lilik., Agus Subroto. Penyelesaian Perkara Peradilan Hubungan Industrial Dalam Teori dan Praktek. Bandung: Alumni, 2011.

Prabowo Soedarso, Bambang. Hukum Dalam Pembangunan Terlanjutkan (Bunga Rampai). Jakarta: Cintya Press, 2008.

Pound, Roscoe. Interpretation of Legal History. USA: WM. W Gaunt \& Sons. Inc. Holmes Florida, 1986.

Rachmat Trijono, Janus. Pengantar Hukum Ketenagakerjaan. Jakarta: Papas Sinar Kinanti, 2014.

Radjagukguk, Erman. "Peranan Hukum Dalam Pembangunan Pada Era Globalisasi: Implikasinya Bagi Pendidikan Hukum Di Indonesia”. Pidato Pengukuhan Diucapkan Pada Upacara Penerimaan Jabatan Guru Besar Dalam Bidang Hukum Pada Fakultas Hukum Universitas Indonesia. Jakarta. 4 Januari 1997.

Reynold, G. Labour Economics and Labour Relation. New Jersey: Prentice Hall, 1974. 
Saleh, Mohammad., Lilik Mulyadi. Pengadilan Hubungan Industrian (Perspektif, Teoretis, Praktik, dan Permasalahannya. Bandung: PT. Citra Aditya Bakti, 2012.

Soedarmoko, R. Perlindungan Pekerja/Buruh Dalam Perjanjian Kerja Waktu Tertentu (PKWT) Sejak Berlakunya Undang-undang Nomor 13 Tahun 2003 tentang Ketenagakerjaan. Semarang: Program Kenotariatan Universitas Diponegoro, 2008.

Soekanto, Soerjono. Pengantar Penelitian Hukum. Jakarta: UI Pers, 1982.

Soepomo, Imam. Pengantar Hukum Perburuhan. Cet. 13. Jakarta: Djambatan, 2013.

Sutedi, Adrian. Hukum Perburuhan. Jakarta: Sinar Grafika, 2009.

Whimbo Pitiyo. Panduan Praktis Hukum Ketenagakerjaan. Jakarta: Visi Media, 2010.

Wijayanti, Asri. Hukum Ketenagakerjaan Pasca Reformasi. Jakarta: Sinar Grafika, 2009.

Zaenal Asikin, Agusfian Wahab. Dasar-dasar Hukum Perburuhan: Jakarta: Rajawali Pers, 2008.

F. Zweig, F. Planning in een vrije Maatschappik. Netherland: Utrecht University, 1949.

.Payment by Result. Geneve: International Labour Office, 1953.

\section{Peraturan Perundang-undangan :}

Indonesia. Undang-Undang Dasar Negara Republik Indonesia Tahun 1945. UUD NRI 1945. Hasil Amandemen.

.Undang-Undang Tentang Pembentukan Propinsi Djawa Barat, UU No. 11 Tahun 1950. .Undang-Undang Tentang Serikat Pekerja/Serikat Buruh. UU No. 21 Tahun 2000. .Undang-Undang tentang Ketenagakerjaan. UU No. 13 Tahun 2003. .Undang-Undang tentang Pembentukan Peraturan Perundang-undangan. UU No. 12 Tahun 2011. 
.Undang-Undang tentang Pemerintahan Daerah. UU No. 23

Tahun 2014 Jo. UU No. 24 Tahun 2015 Jo. UU 23 Tahun 2014.

.Peraturan Pemerintah tentang Pengupahan. PP No. 78

Tahun 2015.

.Peraturan Pemerintah tentang Perlindungan Upah. PP No. 8

Tahun 1981

.Peraturan Pemerintah tentang Pembagian Urusan

Pemerintahan antara Pemerintah, Pemerintahan Daerah Provinsi dan

Pemerintahan Daerah Kabupaten/Kota. PP No. 38 Tahun 2007

.Keputusan Presiden tentang Dewan Pengupahan. KepPres

No. 107 Tahun 2004.

.Keputusan Menteri Tenaga Kerja dan Transmigrasi tentang

Tata Cara Penangguhan Pelaksanaan Upah Minimum. KepMen No. 231/Men/2003

.Peraturan Menteri Tenaga Kerja dan Transmigrasi tentang

Komponen dan Pelaksanaan Tahapan Pencapaian Kebutuhan Hidup

Layak. PerMen No. 13 Tahun 2012

.Peraturan Menteri Tenaga Kerja dan Transmigrasi tentang

Upah Minimum. Permen Nomor 7 Tahun 2013.

.Peraturan Daerah Provinsi DKI Jakarta tentang

Ketenagakerjaan. Perda No. 6 Tahun 2004.

.Peraturan Daerah Provinsi DKI Jakarta tentang Organisasi

Perangkat Daerah. Perda No. 12 Tahun 2014.

.Peraturan Daerah Kabupaten Karawang tentang

Pembentukan Sekretariat Daerah, Sekretariat DPRD, Dinas Daerah,

Lembaga Teknis Daerah, Kecamatan dan Kelurahan. Perda No. 9 Tahun 2011

.Peraturan Daerah Kabupaten Karawang tentang

Penyelenggaraan Ketenagakerjaan. Perda No. 1 Tahun 2011.

.Keputusan Gubernur Jawa Barat Nomor: 561/Kep.1405-

Bangsos/2012 tentang Upah Minimum Kabupaten/Kota di Jawa Barat

Tahun 2013. 
.Keputusan Gubernur Jawa Barat Nomor: 561/Kep.1636Bangsos/2013 tentang Upah Minimum Kabupaten/Kota di Jawa Barat Tahun 2014.

.Keputusan Gubernur Jawa Barat Nomor: 561/Kep.1746Bangsos/2014 tentang Perubahan Atas Keputusan Gubernur Jawa Barat Nomor: 561/Kep.1581-Bangsos/2014 tentang Upah Minimum Kabupaten/ Kota di Jawa Barat Tahun 2015.

.Peraturan Bupati Kabupaten Karawang Nomor 12 Tahun 2012 tentang Rincian Tugas, Fungsi dan Tata Kerja, Dinas Tenaga Kerja dan Transmigrasi Kabupaten Karawang. 